\title{
Histological Changes of Electric Yellow Cichlid (Labidochromis caeruleus) Exposed to Acute and Chronic Cadmium Concentrations
}

\author{
Semra Küçük,a,", Sema Midilli, ${ }^{1, b}$, Mehmet Güler,c, Deniz Çoban',d \\ ${ }^{1}$ Department of Aquaculture Engineering and Fisheries, Faculty of Agriculture, Adnan Menderes University, 09100 Aydin, Turkey
} *Corresponding author

\begin{tabular}{l|l}
\hline A R T I C L E I N F O & A B S T R A C T \\
Research Article & $\begin{array}{l}\text { In this study, electric yellow cichlid were (Labidochromis caeruleus) exposed to acute cadmium } \\
(\mathrm{Cd}) \text { concentrations }\left(0,50,60,70,80 \mathrm{mg}^{-1}\right) \text { for } 72 \mathrm{~h} \text {, and chronic Cd concentrations }(0.00,0.25, \\
\left.0.50,1.00,2.00 \mathrm{mg} \mathrm{l}^{-1}\right) \text { for } 20 \mathrm{~d} \text { to examine histological alternation. In addition to the recovery was } \\
\text { detected after } 10 \mathrm{~d} \text {. After chronic trial, rest of the fish were exposed to just water not containing } \\
\text { cadmium for } 10 \text { day for recovery. Gills, liver, muscle, and spleen samples were collected from } \\
\text { randomly selected fish. The tissue samples prepared with standard techniques for haematoxylin and } \\
\text { eosin (H\&E). Cadmium depending on concentrations increase caused severe disorders on fish. After } \\
\text { acute exposure, several changes were detected such as edema, hyperplasia, breakdown in epithelial } \\
\text { Accepted : 23/07/2019 } \\
\text { tissues of gills; vacuolation and necrosis in liver; increase of hemosterin clustering and necrosis in } \\
\text { spleen. After chronic exposure, some symptoms were also found such as edema, aneurysm, } \\
\text { degermation of secondary lamellae in gills; degeneration and necrosis in liver; degeneration and } \\
\text { granulomas in spleen. Additionally, after recovery of chronic Cd exposure some of the same } \\
\text { symptoms were observed such as edema, hyperplasia and aneurysm in gills; vacuolar degeneration } \\
\text { and necrosis in liver; granulomas and degeneration in spleen. }\end{array}$ \\
$\begin{array}{l}\text { Keywords: } \\
\text { Histology } \\
\text { Labidochromis caeruleus } \\
\text { Acute }\end{array}$ & $\begin{array}{l}\text { Chronic }\end{array}$
\end{tabular}

Türk Tarım - Gıda Bilim ve Teknoloji Dergisi 7(8): 1216-1221, 2019

\section{Akut ve Kronik Kadmiyum Konsantrasyonlarına Maruz Bırakılmış Sarı Prenses Balıklarının Histolojik Değişiklikleri}

\begin{tabular}{|c|c|}
\hline M A K A L E B İ L G İ S İ & j $\mathrm{Z}$ \\
\hline $\begin{array}{l}\text { Anahtar Kelimeler: } \\
\text { Kadmiyum toksisitesi } \\
\text { Histoloji } \\
\text { Labidochromis caeruleus } \\
\text { Akut } \\
\text { Kronik }\end{array}$ & $\begin{array}{l}\text { Bu çalışmada, histolojik değişimleri incelemek için sarı prenses balıkları (Labidochromis caeruleus) } \\
\text { akut cadmiyum konsantrasyonlarına }\left(0,50,60,70,80 \mathrm{mg} \mathrm{l}^{-1}\right) 72 \text { saat süreyle ve kronik kadmiyum } \\
\text { konsantrasyonlarına }\left(0,00 ; 0,25 ; 0,50 ; 1,00 ; 2,00 \mathrm{mg} \mathrm{l}^{-1}\right) 20 \text { gün süreyle maruz bırakılmıştır. Ayrıca } \\
\text { kronik deneme sonunda arta kalan balıklar } 10 \text { gün süreyle kadmiyum içermeyen temiz suya maruz } \\
\text { bırakılmıştır. Bu iki denemeden sonra seçilmiş balıklardan solungaç, karaciğer ve dalak örnekleri } \\
\text { toplanmıştır. Doku örnekleri standart hematosilen-eozin tekniğiyle hazırlanmıştır. Kadmiyum artan } \\
\text { konsantrasyonlara bağlı olarak balıklarda önemli bozukluklara neden olmuştur. Akut maruziyet } \\
\text { sonrası solungaçlarda ödem, hiperplazi, epitel dokuda bozukluklar; karaciğerde vakuoleşme ve } \\
\text { nekroz; dalakta hemosterin kümeciklerinde artış ve nekroz gibi çeşitli bozukluklar saptanmıştır. } \\
\text { Kronik maruziyet sonrasında solungaçlarda ödem, anörizm, sekonder lamellerde dejenerasyon; } \\
\text { karaciğerde dejenerasyon ve nekroz; dalakta dejenerasyon ve granuloma gibi bazı semptomlar } \\
\text { bulunmuştur. Ayrıca kronik kadmiyum maruziyetinden sonraki iyileşme evresinde, solungaçlarda } \\
\text { ödem, hiperplazi ve anörizm; karaciğerde vakular dejenerasyon ve nekroz; dalakta granüloma ve } \\
\text { dejenersyon gibi bazı benzer semptomlar gözlenmiştir. }\end{array}$ \\
\hline
\end{tabular}




\section{Introduction}

Nowadays, water pollution is an important problem in the world. There are many pollutants present in the environment. Heavy metals are more vital than others. They are generally found trace amount in the environment. After industrial, agricultural and mining activities, huge amount of waste discharged to seas, lakes and rivers without purification (Marcussen et al., 2007). It has been reported that heavy metals accumulated in aquatic animals (Abdel-Warith et al., 2011; Jalaludeen et al., 2012; Youis et al., 2013). In such manner, they participate to food chain and increased from one level to another. At the end, they cause a dangerous situation for humans, in the upper level of food chain (Özkan et al., 2018).

There are many studies about heavy metal accumulation in fish (Kalay and Canl1, 2000; Olvisk et al., 2001; Mol et al., 2010; Begum et al., 2013; Bashir et al., 2013). They showed that heavy metals accumulated in viseral organs and muscle tissue of fish. Heavy metals participate in many biochemical activities in fish (Olsson, 1998). As a result of that, they cause many advers effects on vital organs (gills, liver, kidney and spleen) of fish.

Some studies on histological alterations of different species of fish exposed to cadmium have been presented. Thophon et al. (2003) exposed white sea bass (Lates calcarifer $)$ to acute cadmium concentrations $(0.0,5.6,10.0$, 18.0, 25.0, $\left.32.0 \mathrm{mg} \mathrm{l}^{-1}\right)$ for $96 \mathrm{~h}$ and chronic cadmium concentration $\left(0.8 \mathrm{mg} \mathrm{l}^{-1}\right)$ for 3 months. Van Dyk et al. (2007) exposed Oreochromis mossambicus to $0.018 \mathrm{mg}^{-1}$ of cadmium $+0.16 \mathrm{mg} \mathrm{l}^{-1}$ of zinc and $0.03 \mathrm{mg} \mathrm{l}^{-1}$ of cadmium $+0.3 \mathrm{mg} \mathrm{l}^{-1}$ of zinc for short period $(96 \mathrm{~h})$ and long period $(672 \mathrm{~h})$. Liu et al. (2011) exposed Synechogobius hasta to acute cadmium concentrations $\left(0.0,0.1,0.2,0.4,0.8,1.6 \mathrm{mg} \mathrm{l}^{-1}\right)$ for $96 \mathrm{~h}$ and chronic cadmium concentrations $\left(0.00,0.10,0.17,0.29 \mathrm{mg} \mathrm{l}^{-1}\right)$ for 15 d. Y1lmaz et al. (2011) exposed Leuciscus cephalus to $0,1,2 \mathrm{mg} \mathrm{l}^{-1}$ of cadmium concentrations for $10 \mathrm{~d}$. Bais and Lokhande (2012) exposed Ophicephalus striatus to 0.63 $\mathrm{mg}^{-1}$ of cadmium concentration for $96 \mathrm{~h}$. Omer et al. (2012) exposed Nil tilapia (O. niloticus) to $5,10 \mathrm{mg} \mathrm{l}^{-1}$ of cadmium concentrations for $7 \mathrm{~d}$. Selvanatan et al. (2013) exposed Clarias batrachus to 0.00, 0.12, 0.17, 0.30, 0.66 $\mathrm{mg} \mathrm{l}^{-1}$ of cadmium concentrations for $30 \mathrm{~d}$. Younis et al. (2015) exposed $O$. niloticus to $1.68,3.36,5.04 \mathrm{mg}^{-1}$ of cadmium concentrations for $20 \mathrm{~d}$.

The electric yellow cichlid, Labidochromis caeruleus is one of the most popularaquarium fish species. It is found in the phylum Chordata, class Actinopterygii, order Perciformes and familiy Cichlidae. They have beautiful yellow color and called as yellow lab cichlid, electric yellow cichlid, yellow labido, lemon yellow lab, yellow prince. They are endemic species in Lake Malawi of Africa. They reach 8-10 cm of maximal length and 6-10 years old in their life spaces. Minimal tank volume should be $114 \mathrm{~L}$. They prefer $23.9-26.1^{\circ} \mathrm{C}$ water temperature, $\mathrm{pH}$ 7.8-8.9 and $10-20^{\circ} \mathrm{dH}$ (dGH or German degree or deutsche Härte) hardness. It is enough to rechange about $10-20 \%$ of tank water in a week. They want rocks and caves on the sandy ground in aquarium. They are mount breeder fish. Egg incubation takes 3-4 weeks (Anonymous, 2019).
There is no information about histological changes of electric yellow cichlid exposed to $\mathrm{Cd}$ in literature. Because of that, this species was prefered to study on this research. Additionally, higher concentrations of cadmium were used in this study. Since $\mathrm{LC}_{50}$ values of cadmium $(50 \%$ mortality for test animals) were preferred to use in acute Cd toxicity. Some studies (Thophon et al., 2003; Y1lmaz et al., 2004; Benjamin and Thatheyus, 2012) were used to detect the $\mathrm{Cd}$ concentrations that studied in this research. The treshhold values for acute $\mathrm{Cd}$ toxicity were found in white sea bass (L. calcarifer) for 96-h LC $_{50} 20.12 \mathrm{mg} \mathrm{l}^{-1}$ (Thophon et al., 2003), guppy (Poecilia reticulata) for 96$\mathrm{h} \mathrm{LC}_{50} 30.4 \mathrm{mg} \mathrm{l}^{-1}$ (Y1lmaz et al., 2004). and tilapia ( $O$. niloticus) for 72-h $\mathrm{LC}_{50} 106.88 \mathrm{mg} \mathrm{l}^{-1}$ (Benjamin and Thatheyus, 2012).

The objectives of this study were to examine the effects on viseral organs and muscle of electric yellow cichlid, Labidochromis caeruleus, exposed to acute, and chronic Cd concentrations.

\section{Materials and methods}

Each Cd concentration was replicated in three different aquaria. Water was renewed daily with the same $\mathrm{Cd}$ concentrations for each concentration. Laboratory temperature was hold constantly at $24^{\circ} \mathrm{C}$. Water parameters were measured once a day with multi parameter (WTW Multi 3420 set G, Weilheim, Germany). Hardness, alkalinity, ammonia and nitrite were measured once at the beginning of experiment. Fish were fed ab libitum once a day. For each aquarium, additional aeration was supplied during the trial. Mortality was recorded every day for each aquarium.

\section{Acute Exposure of Cd Concentration}

This study consist of two trials: acute and chronic exposures. In the acute trial, laboratory cultured fish were used $(1.95 \pm 0.18 \mathrm{~g}$ and $51.79 \pm 1.60 \mathrm{~mm}, \mathrm{n}=10)$ and ten fish were stocked per $5 \mathrm{~L}(35 \times 16 \times 25 \mathrm{~mm})$. They were starved for $24 \mathrm{~h}$ before experiment and they were exposed to 0,50 , $60,70,80 \mathrm{mg} \mathrm{l}^{-1}$ of cadmium chloride $\left(\mathrm{CdCl}_{2} \cdot \mathrm{H}_{2} \mathrm{O}\right.$, Fluka catalog no: 20899-25G-F) for $72 \mathrm{~h}$. After 24, 48 and $72 \mathrm{~h}$, four fish were randomly selected from each aquarium to collect their gills, liver, spleen and muscle tissues.

\section{Chronic Exposure of Cd Concentration and Recovery}

In the chronic trial also, laboratory cultured fish were used $(6.43 \pm 1.32 \mathrm{~g}$ and $71.41 \pm 4.8 \mathrm{~mm}, \mathrm{n}=15)$, and fifteen fish were stocked per $15 \mathrm{~L}(50 \times 20 \times 30 \mathrm{~mm})$. They were exposed to $0.00,0.25,0.50,1.00,2.00 \mathrm{mg} \mathrm{l}^{-1}$ of cadmium chloride $\left(\mathrm{CdCl}_{2} \cdot \mathrm{H}_{2} \mathrm{O}\right.$, Fluka catalog no: 20899-25G-F) for $20 \mathrm{~d}$. After 10 and $20 \mathrm{~d}$, four fish were randomly selected from each aquarium to collect their gills, liver, and spleen and muscle tissues.

In the recovery part of chronic trial, the rest of the alive fish from chronic trial were hold in clean water for $10 \mathrm{~d}$ to get ride of $\mathrm{Cd}$ accumulation from their bodies. They were stocked in $5 \mathrm{~L}$ of clean water $(35 \times 16 \times 25 \mathrm{~mm})$. After $10 \mathrm{~d}$, four fish were randonly selected from each aquarium to collect their gills, liver, spleen and muscle tissues. 


\section{Histological Analysis}

Fish were anaesthetized with 400-500 $\mathrm{mg} \mathrm{l}^{-1}$ tricaine methansulphonate (MS-222) after each trial (Topic Popovic et al., 2012). Gill, liver, and spleen tissue samples were collected from randomly selected fish and fixed in the $10 \%$ of formalin for at least $24 \mathrm{~h}$. Then, they were dehydrated in water and graded ethanol concentrations (distelled water, 70, 80, 96, 100\%) and xylene (100\%) (Roberts, 2012), embedded in paraffin wax and cut in a rotary microtome (Leica RM 2125 RTS, Nussloch, Germany) about $5 \mu$. After that, those sections mounted on glass slides and deparaffinized in xylen and stained with hematoxylin and eosin (H\&E) method (Culling et al., 1985). Tissue preparations were examined by a light microscope (Euromex Novex B series, Arnhem, Netherlands). Symptoms were recorded by taking microphotographs by microcamera (Novex Cmex DC 5000, Arnhem, Netherlands)

\section{Results}

For two trials, water quality parameters are given in Table 1. In the acute trial, at $50-80 \mathrm{mg} \mathrm{l}^{-1}$ of $\mathrm{Cd}$ concentrations, several symptoms were seen such as edema, hyperplasia in the gill cells (Figure 1); degeneration, vacuolation (Figure $2 \mathrm{~B}$ and 2C), and necrosis (Figure 2D) in the liver cells; increase of homesiderin clustering and necrosis in spleen cells (Figure $3)$. No symptom was detected in muscle tissues. The survival rate was $100 \%$ during $72 \mathrm{~h}$, at acute $\mathrm{Cd}$ exposure.

After chronic trial, Cd exposure caused some clinical symptoms that could be seen by eyes such as hemorrhagic liver at 1.00-2.00 $\mathrm{mg} \mathrm{l}^{-1}$ of $\mathrm{Cd}$, hydropic spleen and anemic gills at $2.00 \mathrm{mg} \mathrm{l}^{-1}$ of $\mathrm{Cd}$. After chronic Cd exposures were fulfilled, some symptoms were detected by microscope examinations. Edema, aneurysm, degeneration of secondary lamellae of gills at $0.25-2.00 \mathrm{mg}^{-1}$ of $\mathrm{Cd}$ (Figure 4); vacuolar degeneration of hepatocyte cells and necrosis in liver (Figure 5); granulomas and degeneration were examined in spleen at $0.25 \mathrm{mg} \mathrm{l}^{-1}$ of $\mathrm{Cd}$ (Figure 6). Their severities increased as $\mathrm{Cd}$ concentration and duration increased. The survival rate was between $53.33-66.67 \%$ for $20 \mathrm{~d}$ (Table 2). After recovery from chronic Cd toxicity, several symptoms were observed such as aneurysm and edema at $0.25-1.00 \mathrm{mg} \mathrm{l}^{-1}$ of Cd; hyperplasia, and edema at $2.00 \mathrm{mg} \mathrm{l}^{-1}$ of $\mathrm{Cd}$ in gills (Figure 7); vacuolar degeneration and necrosis in liver at $0.25-2.00 \mathrm{mg} \mathrm{l}^{-1}$ of $\mathrm{Cd}$ (Figure 8); granulomas and degeneration in spleen at $0.25-2.00 \mathrm{mg}^{-1}$ of Cd (Figure 9). The survival rate was between $30.0 \%$ and $60.0 \%$ (Table 2).

Table 1 Water quality parameters of water source during the acute, and chronic trials, and recovery

\begin{tabular}{l|rrr}
\hline \multirow{2}{*}{ Parameter } & \multirow{2}{*}{ Acute Trial } & \multicolumn{2}{c}{ Chronic Trial } \\
\cline { 2 - 4 } & $24.1 \pm 0.44$ & $23.2 \pm 0.68$ & Recovery Part \\
\hline Temperature & $8.85 \pm 0.16$ & $8.61 \pm 0.23$ & $22.8 \pm 0.23$ \\
pH & $8.1 \pm 0.04$ & $7.90 \pm 0.56$ & $8.97 \pm 0.08$ \\
Oxygen & 738.0 & 738.0 & $7.83 \pm 0.07$ \\
Hardness & 609.0 & 609.0 & 738.0 \\
Alkalinity & 0.22 & 0.22 & 609.0 \\
Ammonia & 0.0069 & 0.0069 & 0.22 \\
Nitrite & & 0.0069 \\
\hline
\end{tabular}

Table 2 Survival in the chronic and recovery trials

\begin{tabular}{l|cc}
\hline \multicolumn{1}{c|}{ Cd Exposure $^{-1}$} & Chronic Trial & Recovery Trial \\
\hline $0.00 \mathrm{mg} \mathrm{l}^{-1}$ & $100.00 \pm 0.00$ & $100.00 \pm 0.00$ \\
$0.25 \mathrm{mg} \mathrm{l}^{-1}$ & $66.67 \pm 0.00$ & $40.00 \pm 28.28$ \\
$0.50 \mathrm{mg} \mathrm{l}^{-1}$ & $53.33 \pm 9.43$ & $50.00 \pm 0.00$ \\
$1.00 \mathrm{mg} \mathrm{l}^{-1}$ & $60.00 \pm 0.00$ & $30.00 \pm 14.14$ \\
$2.00 \mathrm{mg} \mathrm{l}^{-1}$ & $66.67 \pm 0.00$ & $60.00 \pm 28.28$ \\
\hline
\end{tabular}

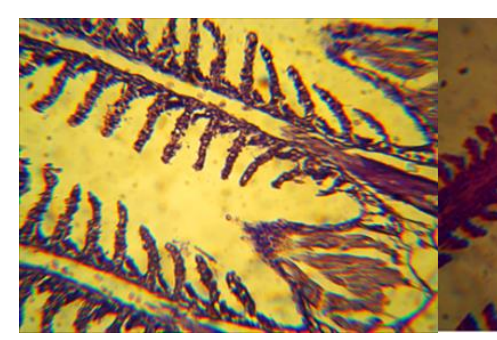

(A)

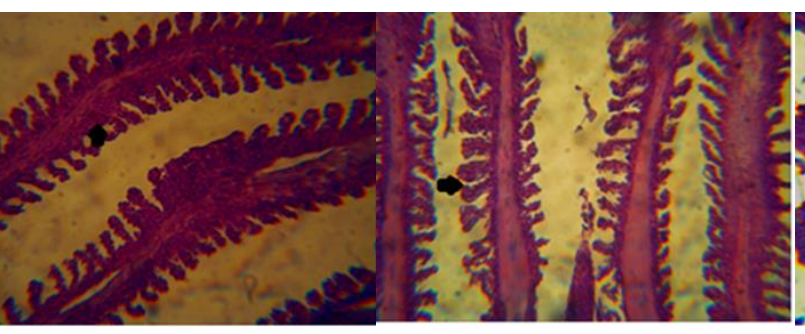

(B)
(C)

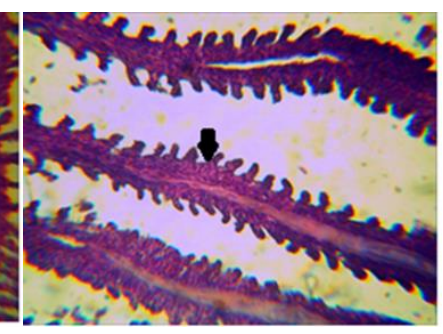

(D)

Figure 1 Gills in the acute trial for $72 \mathrm{~h}(40 \times \mathrm{H} \& \mathrm{E}), \mathrm{A}$ : Control, B: hyperplasia in the $50 \mathrm{mg} / \mathrm{L} \mathrm{Cd}$ exposure, C: hyperplasia in the $60 \mathrm{mg} / \mathrm{L} \mathrm{Cd}$ exposure, D: hiperplasia and degeneration in the $80 \mathrm{mg} / \mathrm{L}$ of Cd exposure 


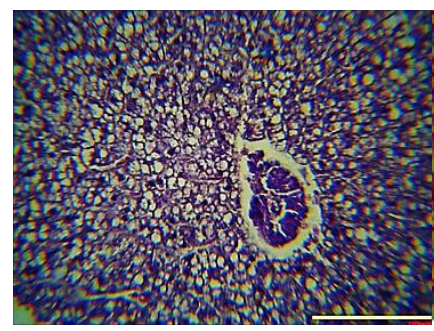

(A)

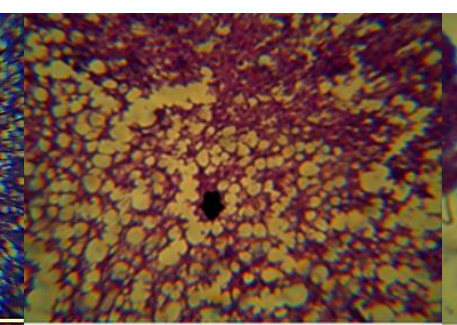

(B)

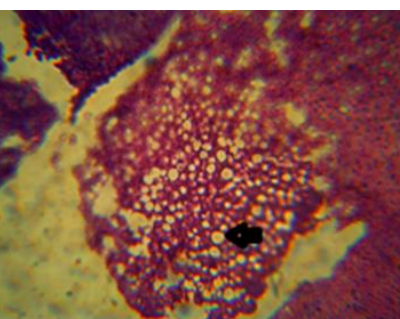

(C)

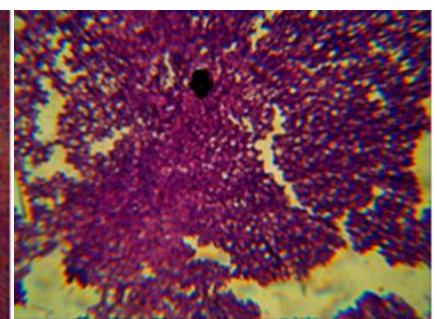

(D)

Figure 2 Liver in the acute trial for $72 \mathrm{~h}(40 \times \mathrm{H} \& \mathrm{E})$, A: Control, B: vacuolations in the $50 \mathrm{mg} / \mathrm{L}$ of Cd exposure, C: vacuolations in the $60 \mathrm{mg} / \mathrm{L}$ of Cd exposure, D: necrosis in the $80 \mathrm{mg} / \mathrm{L}$ of Cd exposure (arrow)

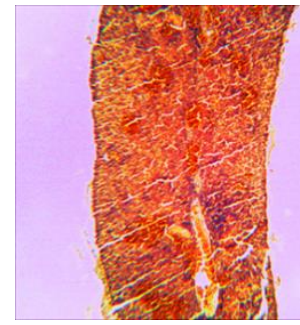

(A)

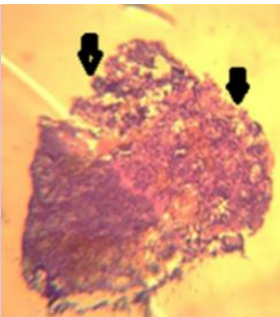

(B)

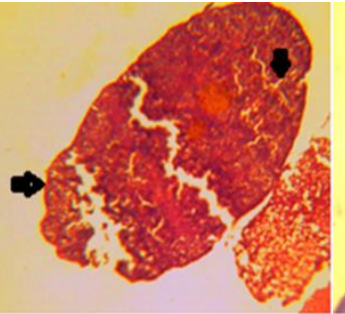

(C)

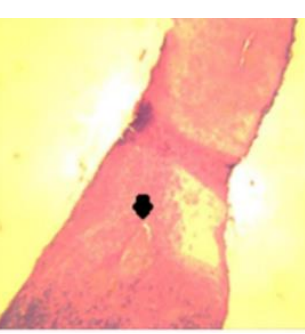

(D)

Figure 3 Spleen in the acute trial for $72 \mathrm{~h}(10 \times \mathrm{H} \& \mathrm{E}), \mathrm{A}$ : Control, B: necrosis in the $50 \mathrm{mg} / \mathrm{L}$ of Cd exposure, C: necrosis in the $60 \mathrm{mg} / \mathrm{L}$ of $\mathrm{Cd}$ exposure, D: homesterin clustering in the $80 \mathrm{mg} / \mathrm{L} \mathrm{Cd}$ exposure (arrow)

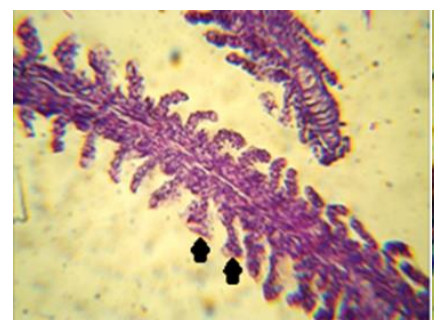

(A)

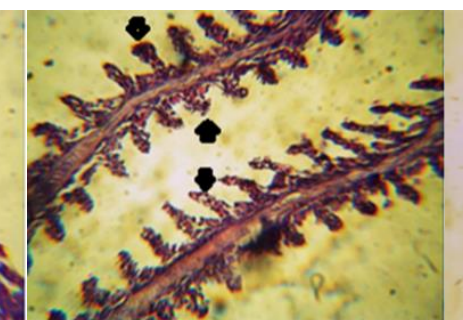

(B)

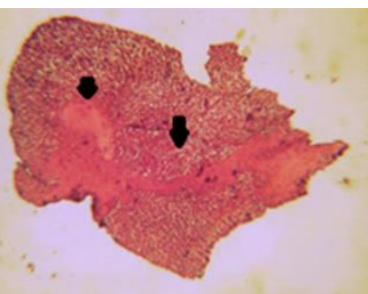

(A)

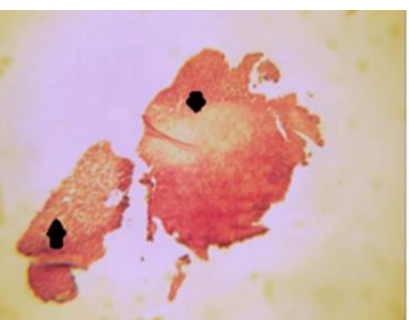

(B)

Figure 4 Gills in the chronic trial for $20 \mathrm{~d}(40 \times \mathrm{H} \& \mathrm{E}), \mathrm{A}$ : Figure 5 Liver in the chronic trial for $20 \mathrm{~d}(10 \times \mathrm{H} \& \mathrm{E})$, edema, aneurysm in the $0.25 \mathrm{mg} \mathrm{l}^{-1}$ of Cd exposure, B: vacuolations and degeneration (arrow) A: $0.25 \mathrm{mg} \mathrm{l}^{-1}$ of Cd degeneration, edeme, and aneurysm in the $2 \mathrm{mg} \mathrm{l}^{-1}$ of $\mathrm{Cd} \quad$ exposure and $\mathrm{B}: 2 \mathrm{mg} \mathrm{l}^{-1}$ of Cd exposure (arrow) exposure (arrow)

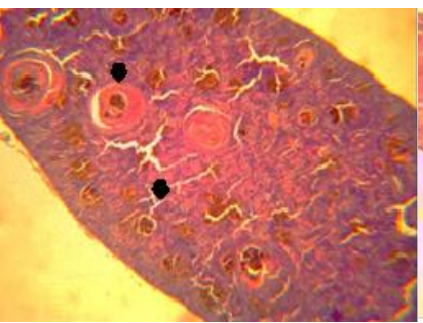

(A)

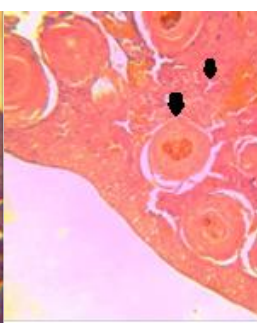

(B)

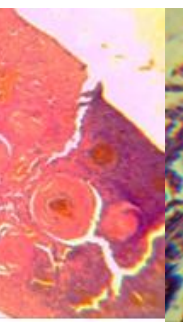

)

Figure 6 Spleen in the chronic trial for $20 \mathrm{~d}(10 \mathrm{x} \mathrm{H} \& \mathrm{E})$, granulomas and degeneration A: $0.25 \mathrm{mg} \mathrm{l}^{-1}$ of Cd exposure and B: $2 \mathrm{mg} \mathrm{l}^{-1}$ of Cd exposure (arrow)

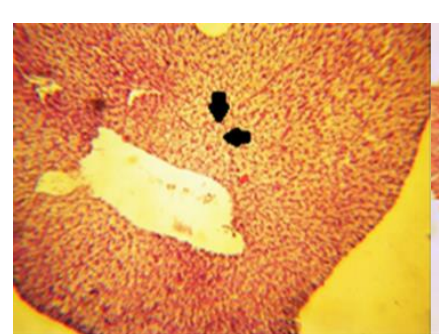

(A)

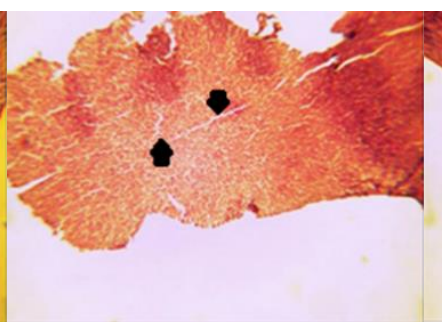

(B)

Figure 8 Liver in the recovery trial for $10 \mathrm{~d}(10 \mathrm{x} H \& \mathrm{E})$, vacuolations and degeneration $\mathrm{A}: 0.25 \mathrm{mg} \mathrm{l}^{-1}$ of $\mathrm{Cd}$ exposure and B: $2 \mathrm{mg} \mathrm{l}^{-1}$ of Cd exposure (arrow)

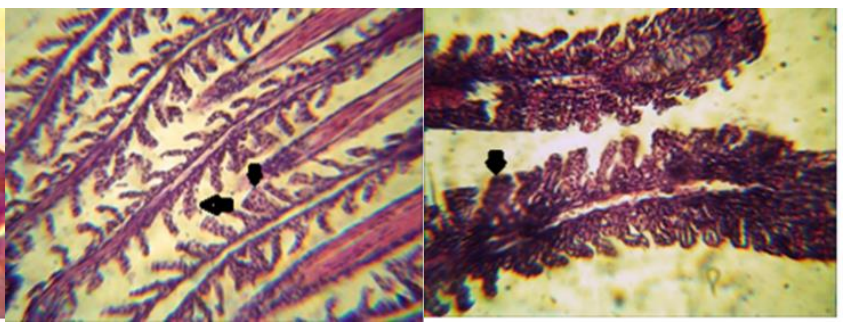

(A)

Figure 7 Gills in the recovery trial for $10 \mathrm{~d}(40 \mathrm{x} \mathrm{H} \& \mathrm{E}), \mathrm{A}$ : edeme and aneurysm in the $0.25 \mathrm{mg} \mathrm{l}^{-1}$ of $\mathrm{Cd}$ exposure, $\mathrm{B}$ : hyperplasia and edema in the $2 \mathrm{mg} \mathrm{l}^{-1}$ of $\mathrm{Cd}$ exposure (arrow)

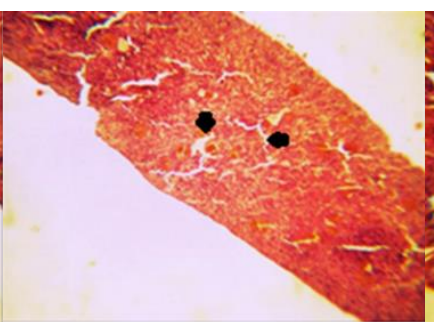

(A)

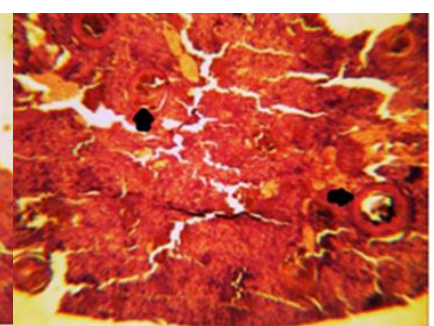

(B)

Figure 9 Spleen in the recovery trial for $10 \mathrm{~d}(10 \mathrm{x} H \& \mathrm{E})$, degeneration and granuloma A: $0.25 \mathrm{mg} \mathrm{l}^{-1}$ of Cd exposure and $\mathrm{B}: 2 \mathrm{mg} \mathrm{l}^{-1}$ of $\mathrm{Cd}$ exposure (arrow) 


\section{Discussion}

Cd exposure causes histological changes in electric yellow cichlid. Because it is reported by Olsson (1998) that decrease of $\mathrm{Ca}^{+2}, \mathrm{Na}^{-}, \mathrm{Cl}^{-}$and $\mathrm{K}^{+}$levels, increase of hyperglycemia and hypermagnesemia in the plasma, increase of mucus cells in intestine and gills, increase of number of chloride cell in the epithelium of gills, and deformations in vertebrate.

Histological effects of $\mathrm{Cd}$ on various species have been investigated in some studies. There are many similar results between our study and previous ones. In this study, edema, aneurysm, hyperplasia, breakdown in epithelial tissues, degeneration of secondary lamellae was identified in gills. Vacuolar degeneration and necrosis in hepatocyte cells of liver, and degeneration and granulomas in spleen were investigated. Thophon et al. (2003) found edema, degeneration of pillar cells, aneurysm, and hyperplasia in gills; and blood congestion of sinusoids, hydropic swelling, vacuolation, and black granulation in liver of $L$. calcarifer. Van Dyk et al. (2007) detected hyalisation, vacuolation and blood congestion in liver of $O$. mossambicus. Liu et al. (2011) reported degeneration of seconder lamellea, aneurysm, edema in gill; blood congestion and vaculation in liver and spleen of S. hasta. Y1lmaz et al. (2011) found degeneration in seconder lamellae, necrosis and hydropic degeneration of chlorid cells in gills; and hydropic degeneration and necrosis in liver of L. cephalus. Bais and Lokhande (2012) observed hypertrophy, degeneration of lamellae, blood congestion in gills; and degeneration, necrosis and hypertrophy in liver of $O$. striatus. Omer et al. (2012) detected fatty vacuolation, necrosis and blood congestion in liver of $O$. niloticus. Selvanatan et al. (2013) found hyperplasia, fusion of seconder lamellae, degeneration of epithelial cells in gills; and vacuolation, necrosis in liver of $C$. batrachus. Younis et al. (2015) reported vacuolation and granulation in liver of $O$. niloticus.

In this study, survival was high (100\%) during the acute trial (72 h) although high $\mathrm{Cd}$ concentrations were used. This survival may be obtained because of high water hardness and alkalinity. Carbonate and bicarbonate ions may tide up with $\mathrm{Cd}$ in water. They precipitated as white powder on the bottom of the aquarium. High hardness and alkalinity could protect fish from high $\mathrm{Cd}$ concentration and decrease Cd toxicity (Pascoe and Evans, 1986; Kiyani et al., 2013).

After recovery of chronic $\mathrm{Cd}$ concentrations, electric yellow cichlids did not become well exactly. $\mathrm{Cd}$ exposure severely affected fish visceral organs. It was observed that edema, aneurysm, hyperplasia in gills; vacuolar degeneration and necrosis in liver; granulomas and degeneration in spleen were still observed on the tissue samples, although clean water used instead of $\mathrm{Cd}$ concentrations. No recovery situation were seen in fish and survival was very low (30-60\%) in this part.

In conclusion, this study was conducted to investigate the histological alterations of electric yellow cichlids after acute $\left(0,50,60,70,80 \mathrm{mg}^{-1}\right.$ for $\left.72 \mathrm{~h}\right)$ and chronic $(0.00$, $0.25,0.50,1.00,2.00 \mathrm{mg} \mathrm{l}^{-1}$ for $\left.20 \mathrm{~d}\right) \mathrm{Cd}$ toxicities and recovery (just water not containing $\mathrm{Cd}$ for $10 \mathrm{~d}$ ). Cd effects were examined on several fish species previously. Many similarities are present between this study and previous ones (Thophon et al., 2003; Van Dyk et al., 2007; Liu et al., 2011; Y1lmaz et al., 2011; Bais and Lokhande, 2012; Omer et al., 2012; Selvanatan et al., 2013; Younis et al., 2015). At $80 \mathrm{mg} \mathrm{l}^{-1}$ of $\mathrm{Cd}$, severities of symptoms were increased such as edema, aneurysm in gills; and vacuolation and degeneration in liver; and granulomas and degeneration in spleen. Acute and chronic $\mathrm{Cd}$ concentrations may cause important disorders in gill, liver and spleen tissues. At 1.00-2.00 $\mathrm{mg} \mathrm{l}^{-1}$ of $\mathrm{Cd}$, severities of symptoms were increased. Three days is not enough time to see Cd damages in fish tissues. It is recommended that histological studies can be conducted more than 10 days to observe important pathological symptoms.

\section{Acknowledgements}

Special thanks to Kılıç Holding and Aydın Adnan Menderes University for their financial supports.

\section{References}

Abdel-Warith AA, Younis EM, Al-Asgah NA, Wahbi OM. 2011. Effect of zinc toxicity on liver histology of Nile tilapia, Oreochromis niloticus. Scientific Research and Essays, 6(17): 3760-3769.

Anonymous, 2019. http://animal-world.com/encyclo/fresh /cichlid/electricyellow.php (Rearch date: 07.07.2019).

Bais UE, Lokhande MV. 2012. Effect of cadmium chloride on histopathological changes in the freshwater fish Ophiocephalus striatus (Channa). International Journal of Zooligal Research, 8: 23-32.

Bashir FH, Othman MS, Mazlan AG, Rahim SM, Simon KD. 2013. Heavy metal concentration in fishes from the coastal water of Kapar and Mersing, Malaysia. Turkish Journal of Fisheries and Aquatic Sciences, 13: 375-382.

Begum A, Mustafa AI, Amin MN, Chowdhury TR, Quraihi SB, Banu N. 2013. Levels of heavy metals in tissues of shingi fish (Heteropneustes fossilis) from Buriganga River, Bangladesh. Environmental Monitoring Assessment, 185: 5461-5469.

Benjamin D, Thatheyus AJ. 2012. Acute toxicity of nickel and cadmium to cichlid fish, Oreochromis mossambicus (Peters). Zoological Research, 2: 19-22.

Culling AF, Allison TR, Barr TW. 1985. Cellulary Patholog Technique. 4.rt Edition, London, UK, Mid-County Press, 46 p.

Kalay M, Canlı M. 2000. Elimination of Essential (Cu, Zn) and non-essential $(\mathrm{Cd}, \mathrm{Pb})$ metals from tissues of a freshwater fish Tilapia zilli. Turkish Journal of Zoology, 24, 429-436.

Kiyani V, Hosynzadeh M, Ebrahimpour M. 2013. Investigation acute toxicity some of heavy metals at different water hardness. International Journal of Advanced Biochemistry Research, 1: 134-142.

Jalaludeen MD, Arunachalam M, Raja M, Nandagopal S, Showket AB, Sundar S, Palanimuthu D. 2012. Histopathology of the gill, liver and kidney tissues of the freshwater fish Tilapia mossambica exposed to cadmium sulphate. International Journal of Advanced Biological Research, 2(4): 572-578.

Liu XJ, Luo Z, Li CH, Xiong BX, Zhao YH, Li XD. 2011. Antioxidant responses, hepatic intermediary metabolism, histology and ultrastructure in Synechogbius hasta exposed to waterborne cadmium. Ecotoxicology and Environmetal Safety, 74: 1156-1163.

Marcussen H, Holm PE, Ha LT, Dalsgaard A. 2007. Food safety aspects of toxic element accumulation in fish from wastewater-fed ponds in Hanoi, Vietnam. Tropical Medicine and International Health, 12: 34-39.

Mol S, Özden Ö, Oymak SA. 2010. Trace metal contents in fish species from Atatürk Dam Lake (Euphrates, Turkey). Turkish Jounal of Fisheries and Aquatic Sciences, 10: 209-213. 
Olvisk PA, Gundersen P, Andersen RA, Zachariassen KE. 2001. Metal accumulation and MT in Brown Trout Salmo trutta from two Norwegian rivers differently contaminated with $\mathrm{Cd}$, $\mathrm{Cu}$ and $\mathrm{Zn}$. Comparative Biochemistry and Physiology Part C Toxicology and Pharmacology, 128: 189-201.

Olsson PE. 1998. Disorders associated with heavy metal pollution. In Leatherlaand JF, Woo PTK, editor. Fish Diseases and Disorders,. Wallingford, UK: Cabi Publishing, $114 \mathrm{p}$.

Omer SA, Elobeid MA, Fouad D, Daghestani MH. 2012. Cadmium bioaccumulation and toxicity in tilapia fish (Oreochromis niloticus). Journal of Animal and Veterinary Advances, 11: 1601-1606.

Özkan E, Taşlıpınar MY, Yeşilkaya Ş. 2019. Ağır Metal Zehirlenmeleri. http://www.jcam.com.tr/files/KATD1599.pdf (07 Temmuz 2019).

Pascoe D, Evans SA, Woodworth J. 1986. Heavy metal toxicity to fish and the influence of water hardness. Archives Environmental Contamination and Toxicology, 15, 481-487.

Roberts, R.J. (2012). Fish Pathology. Fourth Edition. Chapter 12. Laboratory Methods, New York, USA, Wiley-Blackwell, 444 p.

Selvanathan J, Vincent S, Nirmala A. 2013. Histopathology changes in freshwater fish Clarias batrachus (Linn.) exposed to mercury and cadmium. International Journal of Life Science and Pharma Research, 3: 11-21.

Thophon S, Kruatrachue M, Upatham ES, Pokethitiyook P, Sahaphong S, Jaritkhuan S. 2003. Histopathological alterations of White seabass, Lates calcarifer, in acute and subchronic cadmium exposure. Environmental Pollution, 121: 307-320.
Topic Popovic N, Strunjak-Perovic I, Coz-Rakovac R, Barisic J, Jadan M, Persin Berakovic A, Sauerborn Klobucar R. 2012. Review: Trivaine methane-sulfonate (MS-222) application in fish anaesthesia. Journal of Applied Ichthyology, 28: 553564.

Van Dyk JC, Pieterse GM, Van Vuren JHJ. 2007. Histological changes in the liver of Oreochromis mossambicus (Cichlidae) after exposure to cadmium and zinc. Ecotoxicology and Environmental Safety, 66: 432-440.

Yilmaz M, Gül A, Karaköse E. 2004. Investigation of acute toxicity and the effect of cadmium chloride $\left(\mathrm{CdCl}_{2} \mathrm{H}_{2} \mathrm{O}\right)$ metal salt on behavior of the guppy (Poecilia reticulata). Chemosphere, 56: 375-380.

Yılmaz M, Ersan Y, Koç E, Özen H, Karaman M. 2011. Toxic effects of cadmium sulphate on tissue histopathology and serum protein expression in European chub, Leuciscus cepahlus (Linnaeus, 1758). Kafkas Üniversitesi Veteriner Fakültesi Dergisi, 17: 131-135.

Younis EM, Abdel-Warith AA, Al-Asgah NA, Ebaid H, Mubarak M. 2013. Histological changes in the liver and intestine of Nile tilapia, Oreochromis niloticus, exposed to sublethal concentrations of cadmium. Pakistan Journal of Zoology, 45(3): 833-841.

Younis E, Abdel-Warith AW, Al-Asgah N, Ebaid H. 2015. Histopathological alterations in the liver and intestine of Nile tilapia Oreochromis niloticus exposed to long-term sublethal concentrations of cadmium chloride. Chinese Journal of Oceanology and Limnology, 33: 846-852. 